\title{
Hubungan Kepercayaan Diri dengan Teknik Dasar Grab Start
}

\author{
Self-Confidence Relationship with Grab Start Basic Techniques
}

\author{
Sony Hasmarita, Rama Adha Septiana \\ STKIP Pasundan, Cimahi, Jawa Barat, Indonesia \\ Sonyhasmarita92@gmail.com, Ramaadha7@gmail.com
}

\begin{abstract}
Abstrak
Tujuan melakukan penelitian ini adalah untuk mengetahui apakah terdapat hubungan antara kepercayaan diri dengan teknik grab start pada mahasiswa UKM Akuatik STKIP Pasundan Cimahi. Metode yang digunakan dalam penelitian ini adalah penelitian deskriptif dengan teknik studi korelasional. Untuk melakukan tes kepercayaan diri dengan pengisian angket kepada mahasiswa UKM Akuatik STKIP Pasundan Cimahi. Setelah itu dilakukan tes teknik awalan grab start. Populasi yang digunakan dalam penelitian ini adalah anggota UKM Akuatik STKIP Pasundan Cimahi yang berjumlah anggota 30 orang, dan penulis mengambil sampel dalam penelitian ini adalah mahasiswa tingkat 1 yang berjumlah sebanyak 15 orang, teknik pengambilan sampel dalam penelitian ini menggunakan teknik sampling jenuh. Berdasarkan data penelitian hasil signifikansi korelasi ganda antara kepercayaan diri dengan teknik dasar grab start, di dapat t tabel adalah 2,16 sedangkan $t$ hitung adalah 6,4684. Dapat dilihat bahwa t hitung $>\mathrm{t}$ tabel sehingga Ho ditolak dan $\mathrm{H}_{1}$ diterima. Dengan kata lain dapat disimpulkan bahwa koefisien korelasi antara x dengan y adalah SIGNIFIKAN. Berarti dapat disimpulkan bahwa terdapat hubungan yang signifikan antara variabel kepercayaan diri secara bersama-sama dengan variabel teknik dasar grab start. Kesimpulan dari penelitian ini bahwa kepercayaan diri mempunyai hubungan yang sangat erat pada seseorang khususnya pada mahasiswa UKM Akuatik STKIP Pasundan Cimahi untuk melakukan berbagai macam aktifitas fisik, khususnya dalam renang yang menunjukan teknik dasar grab start.
\end{abstract}

Kata kunci : Kepercayaan diri, Teknik Dasar Grab Start

\begin{abstract}
The purpose of conducting this research is to find out whether there is a relationship between selfconfidence and the technique of grab start on students of Aquatic Animal Science STKIP Pasundan Cimahi. The method used in this study is descriptive research with correlational study techniques. To carry out a self-confidence test by filling out a questionnaire to students of the STKIP Pasundan Aquatic Sciences in Cimahi. After that the technical test for the start grab start. The population used in this study was a member of the STKIP Pasundan Cimahi Aquatic UKM which numbered 30 members, and the authors took samples in this study were 15 level 1 students, the sampling technique in this study used saturated sampling techniques. Based on research data the results of the significance of the double correlation between self-confidence and the basic technique of grab start, can be t table is 2.16 while $t$ count is 6.4684 . It can be seen that $t$ count $>$ t table so that Ho is rejected and $H_{1}$ is accepted. In other words it can be concluded that the correlation coefficient between $x$ and $y$ is SIGNIFICANT. It means that it can be concluded that there is a significant relationship between the variables of self-confidence together with the basic technique of grab start. The conclusion of this study is that self-confidence has a very close relationship with someone, especially in the STKIP Pasundan Cimahi Aquatic Student to do various kinds of physical activities, especially in swimming which shows the basic technique of grab start.
\end{abstract}

Keywords: Self-confidence, Basic Grab Start Technique 


\section{PENDAHULUAN}

Renang adalah olahraga yang berbeda dengan olahraga lainnya karena olahraga ini dilakukan di dalam air dan digemari oleh berbagai kalangan masyarakat di Indonesia, mulai dari anak-anak, remaja, sampai dengan dewasa, baik di perkotaan maupun di pedesaan. Olahraga renang juga bisa bermanfaat bagi kesehatan tubuh.

Menurut Kurnia (2016) dalam olahraga renang terdapat aspek-aspek yang mempengaruhi keberhasilan renang seperti aspek teknik, aspek fisik, dan aspek mental. Aspek teknik merupakan kesesuaian antara teori yang sudah dipelajari atau didapat dengan aplikasinya di lapangan, seperti gerakan meluncur, gerakan lengan, gerakan kaki, gerakan tungkai dan cara pengambilan nafas ketika berada di dalam air. Olahraga renang memiliki beberapa teknik gaya diantaranya, gaya bebas, gaya punggung, gaya dada dan gaya kupu-kupu. Untuk menunjang hasil atau prestasi dalam olahraga renang, seorang perenang perlu menguasai skill penunjang lainnya, yaitu teknik start. Teknik start yang baik dapat membantu seorang perenang untuk mengikis ataupun memperoleh catatan waktu yang baik. Salah satu teknik start yang paling mudah karena langkah-langkahnya yang tidak terlalu sulit dan harus dikuasai oleh seorang perenang adalah teknik grab start (Amin, et al, 2012). Seorang perenang harus betul-betul memperhatikan teknik ini, karena semakin besar tingkat penguasaan teknik, maka semakin rendah tingkat kesalahan yang dimiliki (Eriza, 2015).

Namun selain harus menguasai teknik dasar grab start yang benar, seorang perenang juga harus mempunyai kondisi fisik yang baik. Dari beberapa macam gaya berenang, salah satu gaya yang sering diterapkan para perenang adalah gaya bebas. Gaya ini merupakan gaya yang tercepat dari semua gaya yang terdapat dalam cabang olahraga renang.

Untuk mencapai teknik renang gaya bebas dengan sempurna setiap perenang harus memiliki kemampuan teknik gaya renang dengan baik terutama pada saat luncuran pertama start, selain itu juga harus memperhatikan faktor-faktor yang menunjang baik dari dalam diri maupun luar diri. Pada gaya renang bebas yang perlu diperhatikan adalah kecepatan, kekuatan dan daya tahan. Oleh karena itu, para perenang harus diberikan latihan yang khusus untuk mengembangkan kecepatan, khususnya untuk mengembangkan kepercayaan diri dalam melakukan teknik dasar grab start saat melakukan luncuran pertama.

Kepercayaan diri sendiri sebagai suatu perasaan yang berisi kekuatan, kemampuan, dan keterampilan untuk melakukan atau menghasilkan sesuatu yang dilandasi keyakinan untuk sukses. Percaya diri merupakan salah satu aspek kepribadian yang sangat penting dalam kehidupan manusia (Reddy, 2014; Skinner, 2013; Husdarta, 2014; Rini, 2014; Hamdan, 2015). Orang yang percaya diri yakin atas kemampuan mereka sendiri serta memiliki pengharapan yang realistis. Dengan adanya rasa percaya diri tentunya diharapkan agar perenang lebih termotivasi dan lebih giat untuk berlatih (Komarudin, 2015). Perenang yang memiliki rasa percaya diri yang tinggi lebih berhasil dalam 
melakukan teknik dasar start renang yang dilatih. Selain kepercayaan diri, motivasi merupakan salah satu aspek mental yang mempengaruhi kemampuan seseorang dalam melakukan gerakan renang.

Seseorang yang percaya diri memiliki ciri-ciri antara lain memliki keyakinan atas kemampuan diri, optimis, objektif, bertanggung jawab, rasional, realistis, mampu menintrospeksi dirinya, tenang, selalu berpikiran positif, dan sebagainya (Risnawati \& Ghufron, 2010; Mardatillah, 2010).

Mastuti (2008) mengemukakan terkait faktor-faktor yang dapat mempengaruhi kepercayaan diri seseorang, antara lain: orangtua, masyarakat, teman sebaya, dan konsep diri. Mengkaji dari faktor-faktor yang mempengaruhi kepercayaan diri, peneliti mengambil kesimpulan bahwa kepercayaan diri dipengaruhi oleh dua faktor, yaitu faktor internal dan faktor eksternal. Faktor internal yaitu konsep diri seseorang, yakni kesadaran seseorang akan keadaan yang membawa pengaruh besar dalam penentuan tingkah laku seseorang. Terbentuknya konsep diri ini berdasarkan persepsi mengenai sikap-sikap lain terhadap seseorang dan atas dasar pengalaman terhadap lingkungan keluarga. Rasa percaya diri akan timbul dan berkembang sesuai dengan kesadaran akan keyakinan dan kemampauan diri untuk menerima dan memahami orang lain sebagai hubungan interaksi yang saling mendukung, baik keluarga atau dalam pergaulan dengan lingkungan sosial. Adapun faktor eksternalnya yaitu lingkungan keluarga dimana lingkungan keluarga akan memberikan pembentukan awal terhadap pola kepribadian seseorang (Kurnia, 2016).

Berdasarkan kajian teori mengenai aspek kepercayaan diri, bagi seorang perenang besar kemungkinan kepercayaan diri ini akan berpengaruh pada teknik dasar grab start renang pada seorang perenang.

\section{METODE PENELITIAN}

Metode penelitian yang digunakan adalah metode deskriptif dengan teknik studi korelasional. Arikunto (2010) Korelasional adalah penelitian yang bertujuan untuk mengetahui sejauh mana variasi-variasi pada suatu faktor berkaitan dengan variasi-variasi pada suatu atau lebih faktor lain bertujuan untuk menemukan ada tidaknya hubungan dan apabila ada berapa kuatnya hubungan serta berat tidaknya hubungan itu. Metode deskriptif korelasional dalam penelitian ini bertujuan untuk mengetahui Hubungan Kepercayaan Diri dengan Teknik Dasar Grab Start. Adapun rancangan dalam penelitian ini sebagai berikut:

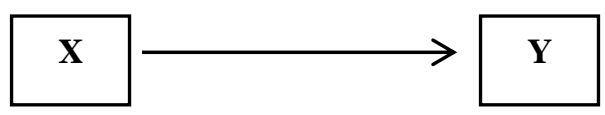

Gambar 1

Desain Penelitian 
Keterangan :

$$
\begin{aligned}
& \text { X : Kepercayaan Diri } \\
& \text { Y : Teknik Dasar Grab Start }
\end{aligned}
$$

Semantara itu, Populasi yang digunakan dalam penelitian ini adalah para perenang yang terdiri atas mahasiswa-mahasiswa yang mengikuti UKM Akuatik STKIP Pasundan Cimahi, tahun 2018 yang berjumlah 30 orang.

Adapun teknik pengambilan sampel pada penelitian ini yaitu menggunakan teknik purposive sampling (Fraenkel, et al, 2012) karena untuk memenuhi penelitian, sampel yang dipilih sesuai dengan kebutuhan dan memenuhi kriteria diantaranya sering hadir dalam setiap pertemuan serta sudah menguasai awalan grab start dengan teknik yang baik dan benar, sehingga dari total populasi sebanyak 30 orang diperoleh 15 orang.

Untuk memperoleh data, dipergunakan Instrumen penelitian diantaranya instrumen penilaian teknik grab start untuk menilai kemampuan teknik grab start perenang, dan instrumen angket kepercayaan diri yang dipergunakan untuk menilai sejauh mana tingkat kepercayaan diri seseorang.

Setelah data diperoleh kemudian data tersebut di analisis. Adapun langkah-langkah analisis data dilakukan sebagai berikut:

1) Uji Mean

$$
\mu=\frac{1}{2}\left(i_{\min }-i_{\max }\right) \Sigma k
$$

2) Standar Deviasi

$$
S D=\frac{1}{6}\left(i_{\min }+i_{\max }\right)
$$

3) Uji Hipotesis

$$
S D=\frac{1}{6}\left(i_{\min }+i_{\max }\right)
$$

4) Regresi Sederhana

$\mathrm{Y}^{\prime}=\mathrm{a}+\mathrm{bX}$

5) Koefisien Determinasi

$\mathrm{KD}=\mathrm{r}^{2} \times 100 \%$

6) Hipotesis Statistika

Ho. : $\rho_{\mathrm{y} 1} \leq 0$

$\mathrm{H}_{1} .: \rho_{\mathrm{y} 1}>0$ 


\section{HASIL DAN PEMBAHASAN}

Hasil

Adapun hasil dari pengolahan dan analisis data yang penulis akan uraikan secara terperinci pada tabel-tabel di bawah ini:

Tabel 1

Hasil Perhitungan Nilai Rata-rata dan Simpangan Baku Variabel

\begin{tabular}{|c|c|c|}
\hline Variabel Penelitian & Rata-rata & Simpangan Baku \\
\hline Kepercayaan Diri & 172,33 & 8,532 \\
\hline Kemampuan Grab Start & 5,6 & 1,121 \\
\hline
\end{tabular}

Berdasarkan tabel 1 di atas, menunjukkan bahwa nilai rata-rata dari hasil penelitian variabel kepercayaan diri adalah 172,33 dan simpangan bakunya adalah 8,532. Sedangkan variabel kemampuan grab start memiliki nilai rata-rata 5,6 dan simpangan bakunya 1,121.

Tahapan selanjutnya dinamakan uji normalitas, yang mana pada proses penghitungannya memiliki keterkaitan antara nilai rata-rata dan simpangan baku pada setiap variabel. Maksud dari pengujian ini adalah untuk mengetahui secara benar, apakah sampel tersebut berasal dari distribusi normal atau sebaliknya. Pengujian normalitas dilakukan dengan pendekatan Liliefors (L). Adapun hasil pengujian normalitas dapat dilihat pada tabel 2 dibawah ini.

Tabel 2

Hasil Pengujian Normalitas Distribusi Data pada tiap Variabel

\begin{tabular}{|c|c|c|c|}
\hline Variabel & Lo & Ltabel & Kesimpulan \\
\hline Kepercayaan Diri & 0,1596 & 0,220 & Normal \\
\hline Kemampuan Grab Start & 0,1981 & 0,220 & Normal \\
\hline
\end{tabular}

Berdasarkan tabel 2 dari data yang telah diambil maka harga mutlak yang paling besar untuk kepercayaan diri ( X ) yaitu sebesar 0,1596. Dengan bantuan tabel F nilai kritis L untuk uji Liliefors untuk ukuran sampel (n) sebanyak 15 dan $\alpha=0,05$, sehingga diperoleh L $\alpha$ 0,220. Kriteria penerimaaan hipotesisnya adalah: Terima Ho jika Lo $<$ L $\alpha=$ Normal, oleh karena Lo $(0,1596)<\operatorname{L} \alpha$ $(0,220)$ maka hipotesis yang diajukan diterima atau dengan perkataan lain dapat dirumuskan bahwa distribusi tersebut "NORMAL".

Dari data yang telah diambil untuk variabel kedua maka harga mutlak yang paling besar untuk kemampuan grab start ( Y ) yaitu sebesar 0,1981. Dengan bantuan tabel F nilai kritis L untuk uji Liliefors untuk ukuran sampel sebanyak (n) 15 dan $\alpha=0,05$, maka didapat L $\alpha$ 0,220. Oleh karena Lo $(0,1981)<\operatorname{L} \alpha(0,220)$ maka hipotesis yang diajukan diterima atau dengan perkataan lain 
dapat dirumuskan bahwa distribusi tersebut "NORMAL".

Langkah selanjutnya ialah melakukan pengujian hipotesis, data diolah melalui teknik penghitungan korelasi dengan skor berpasangan (Skor Kasar). Berikut ini adalah hasil pengolahan data yang dilakukan :

Tabel 3

Hasil Penghitungan Korelasi (Koefisien Korelasi)

\begin{tabular}{|c|c|}
\hline Variabel & Koefisien Korelasi (r) atau (rho) \\
\hline X dengan Y & 0,8735 \\
\hline X dengan Y & 0,9179 \\
\hline
\end{tabular}

Berdasarkan penghitungan korelasi tersebut, terdapat hubungan kepercayaan diri dengan kemampuan grab start sebesar 0,8735. Serta korelasi kepercayaan diri dengan kemampuan grab start adalah sebesar 0,9179. Selanjutnya koefisien korelasi akan digunakan dalam uji signifikansi korelasi.

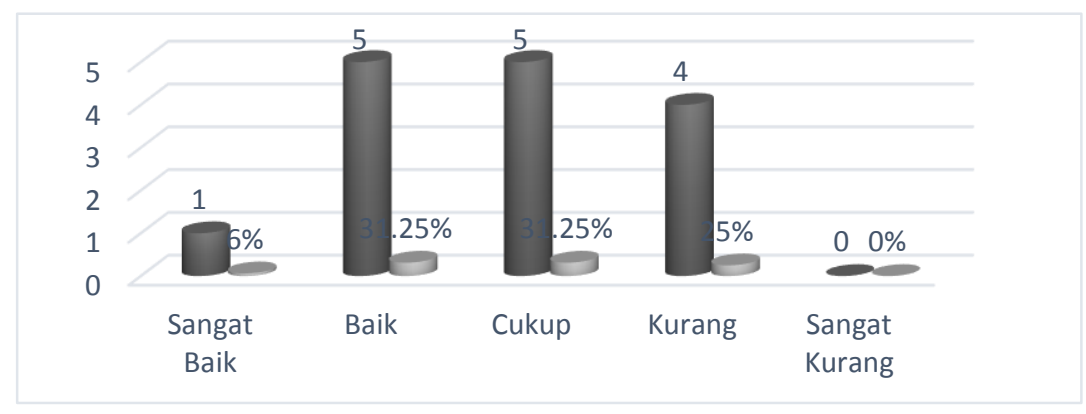

\section{Gambar 2. Histogram Hasil Kepercayaan Diri}

Dari histogram diatas dapat dilihat bahwa hasil kepercayaan diri dari sampel adalah sebagai berikut: Kategori sangat kurang tidak ada siswa yang mendapatkan kategori tersebut, kategori kurang sebanyak 4 orang (25\%), kategori cukup sebanyak 5 orang (31,25\%), kategori baik sebanyak 5 orang $(31,25 \%)$, kategori sangat baik sebanyak 1 orang $(6 \%)$.

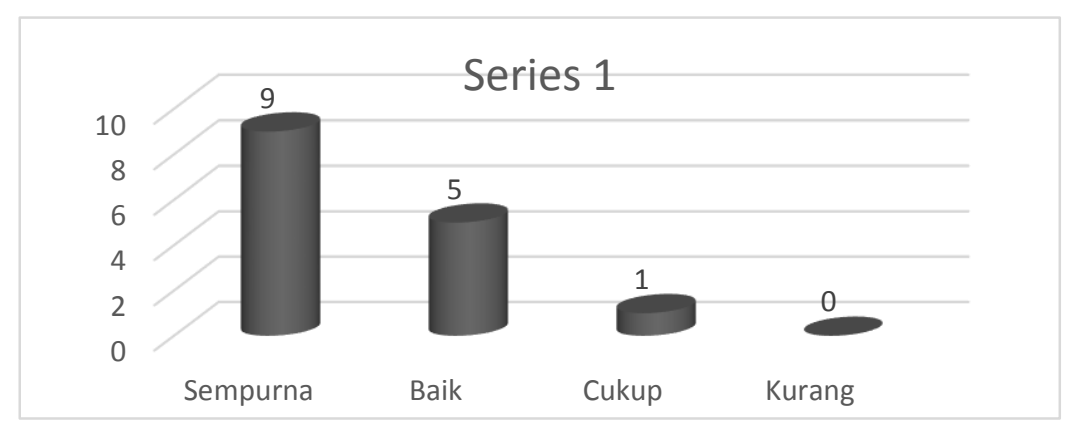

Gambar 3. Histogram Hasil Grab Start 
Dari histogram diatas dapat dilihat bahwa hasil tes Grab start dari sampel adalah sebagai berikut: Kategori kurang tidak ada siswa yang mendapatkan kategori tersebut, kategori cukup sebanyak 1 orang, kategori baik sebanyak 5 orang, kategori sempurna sebanyak 9 orang. Dengan jumlah keseluruhan sampel sebanyak 15 orang.

Selanjutnya adalah menguji signifikansi koefisien korelasi antara tingkat percaya diri dengan kemampuan teknik grab start pada mahasiswa UKM Akuatik. Hasilnya dapat dilihat pada tabel 4 di bawah ini:

Tabel 4

Hasil Penghitungan Signifikansi Korelasi

\begin{tabular}{|c|c|c|c|c|}
\hline Korelasi & $\mathrm{t}$ hitung & $\mathrm{t}$ tabel & Ho & Kesimpulan \\
\hline rxy & 6,4684 & 2,16 & Ditolak & Signifikan \\
& & & & \\
\hline
\end{tabular}

Berdasarkan hasil penghitungan uji signifikansi koefisien korelasi antara variabel kepercayaan diri dengan kemampuan grab start diperoleh thitung sebesar 6,4684 sedangkan $\mathrm{t}$ tabel dengan $\mathrm{dk}=15$ pada taraf nyata $\alpha=0,05$ diperoleh nilai sebesar 2,16 dilihat pada tabel distribusi $\mathrm{t}$, kesimpulannya $\mathrm{t}$ hitung > t tabel. Maka Ho ditolak, artinya terdapat hubungan yang signifikan antara kepercayaan diri dengan kemampuan grab start. Dengan perkataan lain dapat dikatakan bahwa terdapat hubungan yang positif antara kepercayaan diri dengan kemampuan grab start.

Setelah itu, penulis melakukan perhitungan Korelasi berganda dan Uji Signifikansi Koefisien Korelasi Ganda Kemampuan Grab Start Ditinjau dari Kepercayaan diri. Dengan cara:

- Menentukan $\mathrm{r}_{\mathrm{X} 1}, \mathrm{r}_{\mathrm{X} 2 \mathrm{Y}}, \mathrm{r}_{\mathrm{X} 1 \mathrm{X} 2}$

Diketahui bahwa nilai koefisien korelasi adalah :

$\mathrm{r}_{\mathrm{X} 1 \mathrm{Y}}=0,8735$

$\mathrm{r}_{\mathrm{X} 1 \mathrm{X} 2}=0,9179$

- Menentukan koefisien korelasi ganda variabel X1 secara bersama-sama dengan variabel Y $\left(\mathrm{r}_{\mathrm{X} 1 \mathrm{X} 2 \mathrm{Y})}\right.$

Hasil penghitungan korelasi ganda diperoleh hasil sebesar 0,8851. Tahap selanjutnya setelah mendapatkan hasil koefisien korelasi ganda ialah melakukan pengujian singnifikansi korelasi ganda. Adapun hasil penghitungannya terdapat pada tabel 5 dibawah ini : 
Tabel 5

Hasil Perhitungan Korelasi Ganda antara Kepercayaan Diri dengan Kemampuan Grab Start

\begin{tabular}{|c|c|c|c|c|}
\hline $\begin{array}{c}\text { Korelasi Ganda } \\
(\mathrm{R})\end{array}$ & Fhitung & $\begin{array}{c}\text { Ftabel } \\
(\alpha 0,05, \mathrm{dk}=2 / 12)\end{array}$ & Ho & Kesimpulan \\
\hline 0,8851 & 21,7011 & 3,80 & Ditolak & Signifikan \\
\hline
\end{tabular}

Berdasarkan tabel di atas, dapat disimpulkan bahwa koefisien korelasi ganda diperoleh $\mathrm{R}$ sebesar 21,7011. Dan setelah itu dilakukan uji signifikansi dan diperoleh Fhitung serta Ftabel pada taraf nyata 0,05 dengan $\mathrm{dk}=(\mathrm{k}) ;(\mathrm{n}-\mathrm{k}-1)(2 / 12)$ diperoleh nilainya sebesar 3,80. Adapun kriteria hipotesisnya adalah: Terima hipotesis (Ho) jika Fhitung $\leq$ Ftabel dengan dk $=(\mathrm{k})$; $(\mathrm{n}-\mathrm{k}-1)$ pada taraf signifikansi $=0,05$, dalam hal lain hipotesis (Ho) ditolak. Dari hasil pengolahan data diperoleh $21,7011 \geq 3,80$ sehingga disimpulkan bahwa hipotesis (Ho) ditolak, artinya terdapat hubungan yang signifikan antara variabel kepercayaan diri (X) secara bersama-sama dengan variabel kemampuan grab start (Y). Dengan perkataan lain dapat dikatakan bahwa semakin tinggi tingkat kepercayaan diri seseorang maka akan lebih baik dan cepat pula dalam penguasaan kemampuan grab start.

\section{Pembahasan}

Berdasarkan pengolahan dan analisis data, diperoleh hasil temuan penelitian sebagai berikut: Berdasarkan pengolahan data, diperoleh hasil penemuan terdapat korelasi positif dan signifikan antara variabel kepercayaan diri (X) terhadap variabel kemampuan grab start (Y). Berikut ini dapat dilihat dari acuan tabel interpretasi nilai $\mathrm{r}$ :

Dari hasil pengolahan data kepercayaan diri (X) dengan kemampuan grab start (Y) diketahui $\mathrm{r}$ sebesar 0,8735 dan termasuk kategori cukup. Dalam hal ini kepercayaan diri memberikan dukungan yang positif terhadap kemampuan grab start. Sehingga hal tersebut dapat diartikan bahwa mahasiswa yang memiliki tingkat kepercayaan diri yang baik, dikatakan akan semakin mudah pula dalam penguasaan kemampuan grab start yang cenderung memiliki tingkat koordinasi yang tinggi. Sehingga dapat disimpulkan bahwa hipotesis yang penulis ajukan sesuai dengan hasil penelitian, yaitu hipotesis diterima. Oleh karena itu untuk mempelajari grab start dengan tingkat koordinasi yang tinggi, akan semakin mudah dipelajari jika kepercayaan dirinya baik pula. Hal ini sesuai dengan teori yang dijelaskan bahwa kepercayaan diri memainkan peranan penting dalam pencapaian prestasi individu, termasuk keberhasilan dalam konteks pendidikan jasmani, olahraga, dan kesehatan. Sedangkan untuk hasil pengolahan dan analisis data yang diperoleh dari kedua variabel yaitu kepercayaan diri dan kemampuan grab start dengan menggunakan teknik koefisien korelasi ganda adalah sebesar 0,8851 dan termasuk kategori cukup. 
Dapat disimpulkan bahwa antara kepercayaan diri memberikan kontribusi positif terhadap penguasaan kemampuan grab start.

\section{KESIMPULAN}

Dari hasil analisis dan pembahasan di atas, dapat di ambil beberapa kesimpulan sebagai berikut:

- Dalam penelitian ini menjelaskan bahwa kepercayaan diri sangat berhubungan dengan kemampuan melakukan grab start.

- Pada umumnya untuk melakukan sesuatu hal, seseorang harus memiliki sikap kepercayaan diri yang awalnya sebagai motivasi diri sendiri bahwa seseorang tersebut dapat melakukan berbagai hal yang akan dilakukannya, khususnya dalam melakukan grab start.

- Setiap orang pasti memiliki kelebihan dan kekurangan kemampuan teknik dasar gerak (grab start) yang berbeda, akan tetapi semua pasti menyadari pentingnya kemampuan teknik dasar gerak untuk kehidupan sehari-hari, karena dengan kemampuan gerak atau fisik yang bagus akan menimbulkan hasil yang baik untuk melakukan suatu aktifitas, khususnya dalam melakukan grab start.

\section{DAFTAR PUSTAKA}

Amin, et al. (2012). Sumbangan Power Otot Tungkai Panjang Tungkai Kekuatan Otot Perut Terhadap Grab Start. Journal of Sport Sciences and Fitness.

Arikunto, S. 2010. Prosedur Penelitian. Jakarta: Rineka Cipta.

Eriza, Dalfin. (2015). Tingkat Keterampilan Teknik Grab Start Renang Gaya Bebas. Jurnal IImiah.

Fraenkel, et al. (2012).How to Design and Evaluate Research in Education. New York: McGraw Hill.

Hamdan (2015) Psikologi olahraga, Jakarta : Anugrah cipta.

Husdarta. (2014). Psikologi Olahraga. Bandung: Alfabeta.

Komarudin. (2015). Psikologi Olahraga (Latihan Keterampilan Mental dalam Olahraga Kompetitif). Bandung: Rosda.

Kurnia, Rizky, O. (2016). Hubungan Antara Kepercayaan Diri Dan Motivasi Dengan Hasil Renang Gaya Dada 30 Meter Pada Siswa Putra Kelas Xi Sma Negeri 16 Bandar Lampung. Bandar Lampung. Fakultas Keguruan Dan Ilmu Pendidikan Universitas Lampung Bandar Lampung.

Mardatillah. (2010). Pengembangan Diri. STIE Balikpapan: Madani.

Mastuti, Indri. (2008). 50 Kiat Percaya Diri. Hi- Jakarta: Frest Publishing.

Reddy, M. M. (2014). A Study of Self Confidence in Relation to Achievement Motivation of D.ed Students. Global Journal for Research Analysis, Vol. 3 No. 8 Tahun 2014. 
Risnawati, Rini \& Ghufron, M.N. (2010). Teori-Teori Psikologi. Yogyakarta: Ar-Ruzz Media Group.

Rini (2016) psikologi, Bandung : Alfabeta.

Skinner, B. R. (2013). The Relationship Between Confidence and Performance Throughout a Competitive Season. All Graduate Plan B and other Reports, Paper Utah State University. United States. 